\title{
REVISITING THE ISOLATED CANAANITE TEMPLE OF TEL MEVORAKH
}

\author{
ITAMAR WEISSBEIN
}

The Institute of Archaeology, The Hebrew University of Jerusalem, Mount Scopus, Jerusalem, Israel, e-mail: itamar.weissbein@mail.huji.ac.il

Received: $29^{\text {th }}$ May 2017, Accepted: $15^{\text {th }}$ September 2017

\begin{abstract}
The isolated Late Bronze temple at Tel Mevorakh was interpreted by its excavator, E. Stern, as a "road sanctuary" which sits on an important trading route, and as a daughter site of Tel Dor. This article, wish to reexamine this interpretation by drawing the attention to the ancient natural landscape which surrounds the temple, especially the Taninim River and the Kabara Marsh. Those major water sources where significant natural barriers which prevented the passage of main roads in this area. Probably, they also formed a political border which divides between Tel Mevorakh and the Carmel Coast. Therefore, this paper offers that the Tel Mevorakh temple was part of the settlement system of the northern Sharon, and was isolated from roads. The main reason that led to the establishment of a cult-site at Tel Mevorakh was its unique natural surroundings, which was related in the minds of its worshipers to the mythical world of the gods.
\end{abstract}

Keywords: Tel Mevorakh, Landscape Archaeology, Sacred Landscape, Canaanite Cult. Temple.

\section{INTRODUCTION}

Tel Mevorakh is a small mound less than 1,000 square meters in size that rises to about 20 meters above its surroundings (See Fig.1). It is located on the Israeli coast, close to the south bank of the Taninim River and in the north entrance to the modern village of Beit-Hanania. The site was excavated from 1973 to 1976 by Ephraim Stern, on behalf of the Hebrew University of Jerusalem. During the excavation 15 strata were identified, starting with the Middle Bronze Age IIA (strata XV-XIV), and ending with the Crusader and Muslim periods (stratum I). Because of the small size of the mound, during most of its occupation, it contains one main structure. A fort in the Middle Bronze Age (MB), ${ }^{1}$ an administrative structure in the Iron Age and an agricultural estate in the Persian and Hellenistic periods (Stern, 1984:1).

\footnotetext{
${ }^{1}$ Noteworthy is Israel Finkelstein's suggestion that already in the MB the mound was a cult site (Finkelstein, 1992:205-206). Indeed the first structure that was built at Tel Mevorakh, on the natural hill (stratum XV), might have been a shrine. It seems to be a small one-room rectangular structure with thick walls. Compare it for example with the temples of Tell Kittan strata V-IV (Eisenberg, 1977) and Tell el-Hayyat - phase 5 (Falconer, 1995: Fig.6a). Unfortunately, the stratum XV building was not excavated entirely, and the few finds that were found in it are not pointing clearly to its nature. This structure is earlier than the ramparts that were constructed in stratum XIII, a stratum in which the site was occupied by a system of rooms with domestic use. Those structures were identified by Stern as a
} 


\section{Fig. 1: Tel Mevorakh, view to the southeast}

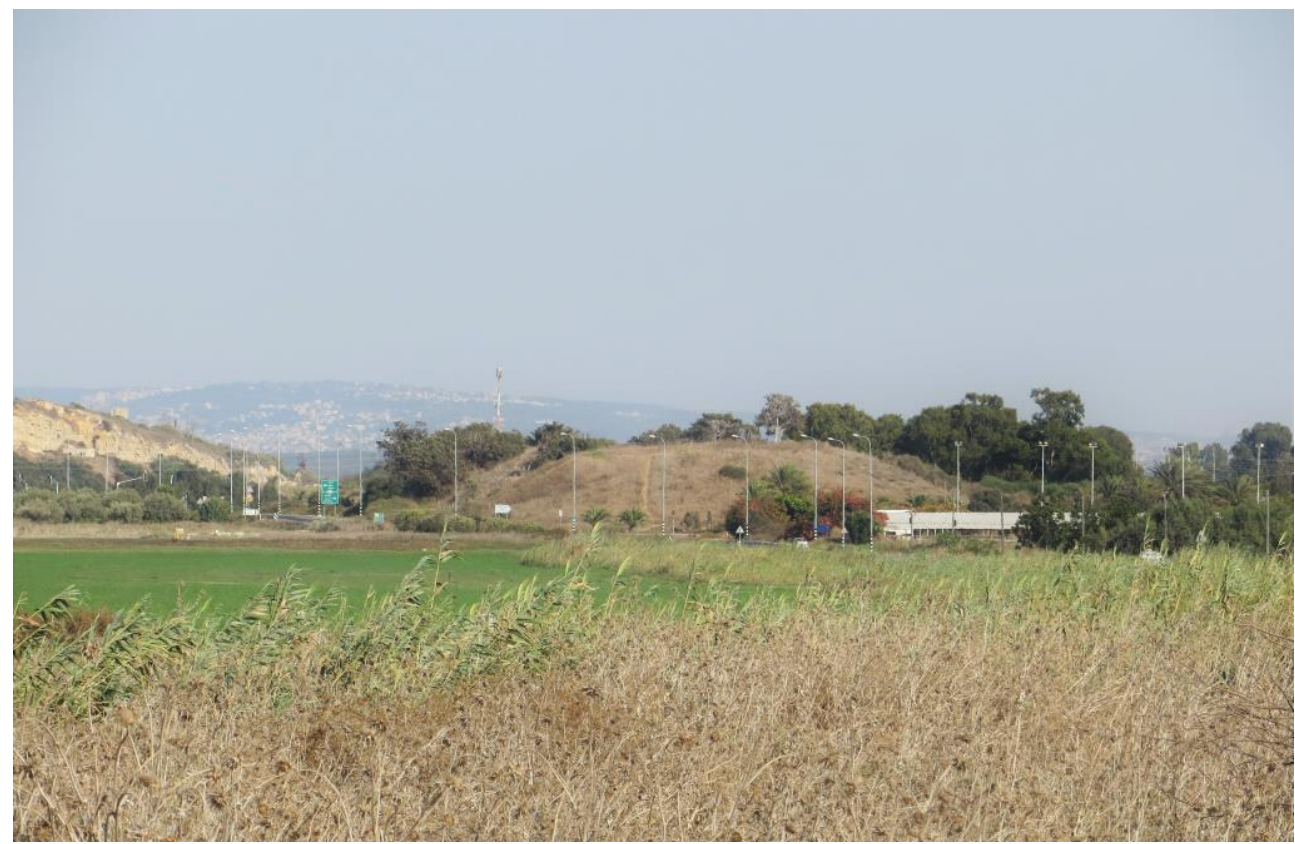

The Late Bronze Age (LB) is represented by three strata, XI to IX. ${ }^{2}$ In each of these, the mound was occupied by a single building that was identified by the excavator as a temple based on its architecture and finds (ibid: 4-9). The best-preserved temple is the earliest one of stratum XI (15 ${ }^{\text {th }}$ century BCE - See Fig.2). It's a small one-room structure, $10 \times 5$ meters in size, with benches alongside its walls, and a raised platform in its northwest corner which was probably the focus of the cult. Although most the building was exposed its entrance was not found. It's located probably at the unexcavated area in the east of the building. Around the temple, patches of pavement were found representing a large open courtyard that surrounds the shrine and was bordered by the MB ramparts from three sides and by an LB temenos-wall in the east. This temple was destroyed and restored shortly after in stratum X (ibid: 4-6, 28, Fig.24; Stern, 1977:89). The temple of Stratum X (14 ${ }^{\text {th }}$ century BCE) was based on the walls of its predecessor and can be seen as a second stage of the same temple with some renovations and additions (Stern, 1984:6-8, 28, Fig.23).

small settlement or fort (Stern, 1984:46-53). From these observations, it seems that there is no clear continuity of cult in Tel Mevorakh from the MB (if indeed the structure of stratum XV was a shrine) to the LB.

${ }^{2}$ Stern also mention a fourth LB stratum, which is later then stratum IX and earlier then VIII $\left(11^{\text {th }}\right.$ century BCE). This unnamed stratum was represented by poorly constructed walls of unclear nature and was dated by Stern to the later part of the $13^{\text {th }}$ century BCE (Stern, 1984:9). 
Fig. 2: Isometric reconstruction of the Tel Mevorakh temple - stratum XI (Stern, 1984 Fig. II; courtesy of Ephraim Stern)

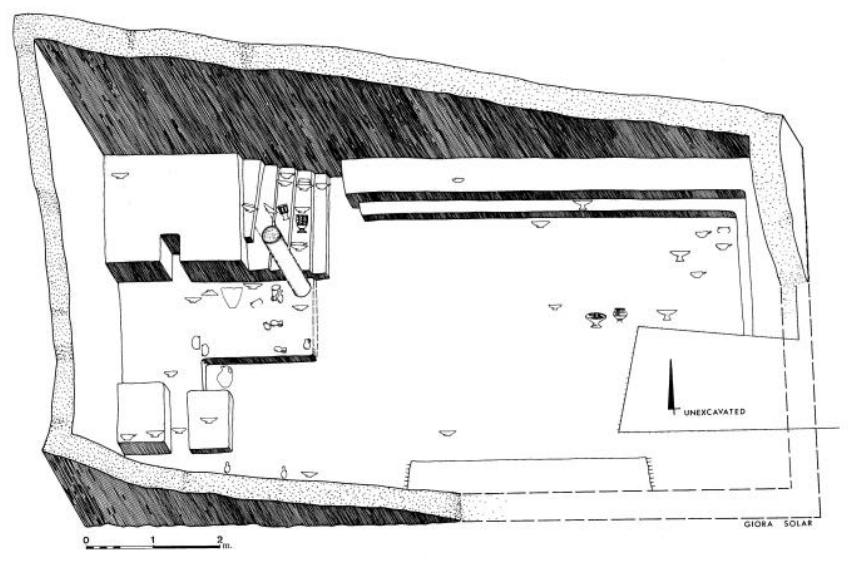

In the $13^{\text {th }}$ century BCE (stratum IX) a new structure was constructed on the remains of the previous temple. Stern suggested that this structure was also a temple, although it had a different plan and orientation (ibid: 8-9, 28, Fig.22; 25). In my opinion, this change points to a lack of continuity between this structure and the previous temple. Because of that, and because there are no finds from this structure, in this article when I refer to the Tel Mevorakh temple I refer to the temple of strata XI and X $\left(15^{\text {th }}\right.$ and $14^{\text {th }}$ century BCE).

The first two temples contained many bowls and a few goblets and chalices together with imported Mycenaean and Cypriot vessels. The more special finds included cylinder seals, beads, cymbals and a few bronze weapons. Two finds that seem to be attributes of the divinity that was once worshiped in the temple are a bronze figurine of a serpent and a bronze pendant that bears a depiction of a star. Those seem to be associated with a cult of a goddess or god, that relates to fertility and perhaps also to healing (ibid: 22-26, 33-35; Münnich, 2005).

The Tel Mevorakh temple is unique in its isolation. It seems to be a solitary building surrounded by a large courtyard, perhaps joined by few auxiliary structures which would be located in the unexcavated area. In any case, it is clearly not a domestic settlement but an isolated temple or a small temple complex, located about $7 \mathrm{~km}$ away from all known settlements of that period (See Fig.3). Quite exceptional case in the archaeology of the LB of the southern Levant (Stern, 1977: 91; Stern, 1976:50). ${ }^{3}$ This raises several questions: What

\footnotetext{
${ }^{3}$ Stern and others (Stern, 1984:36; Finkelstein, 1986:310; Knauf, 1978) list a few more LB isolated temples: the Fosse Temple, Tell Deir 'Alla, Amman airport and the Temple at Timna. From those temples, only the one at Timna is really "isolated", but its context is very different than that of Tel Mevorakh, and was interpreted (correctly) as part of the mining activity in the site (Rothenberg, 1993:1482-1483). The Fosse temple located at the foot of the mound of Lachish clearly should be seen as an integral part of the cultic activity at this city at least in the time of Fosse Temple II and III. In the time of Fosse Temple I, the existence of a city on the mound is not yet clear. From the $15^{\text {th }}$ century remains on the mound known today, there is a possibility that Fosse Temple I was isolated (Singer-Avitz, 2004:1021; Ussishkin, 2004:58). The temple of Tell Deir 'Alla is not isolated at all; it is part of a settlement. The size of Tell Deir 'Alla is about 4.5 hectares. And in the excavations, a few more structures (except for the temple) were excavated (Franken, 1992:37-38, 163). The excavator's
} 
was the reason that led to the establishment of a cult site in this specific isolated location? What was the nature of rituals that took place in it, and who built and worshiped in it? Those questions are in a way intertwined, and they were partly addressed before, especially by the excavator, Ephraim Stern, and also briefly by Amihai Mazar, Israel Finkelstein, and others.

\section{Fig. 3: General map of Tel Mevorakh and other LB sites (courtesy of Haggai Cohen} Klonymus):

1) Akko; 2) Tel Keisan; 3) Tel Abu Hawam; 4) Tel Qashish; 5) Yokneam; 6) Megiddo; 7) Tel Shiqmona; 8) Tel Megadim; 9) Tel Nami; 10) Dor; 11) Tel Ara; 12) Kh. Sitt Leila; 13) Tel Eran; 14) Tel Esur; 15) Tel Zomera; 16) Tel Zeror; 17) Tell Jatt; 18) Tel Girit.

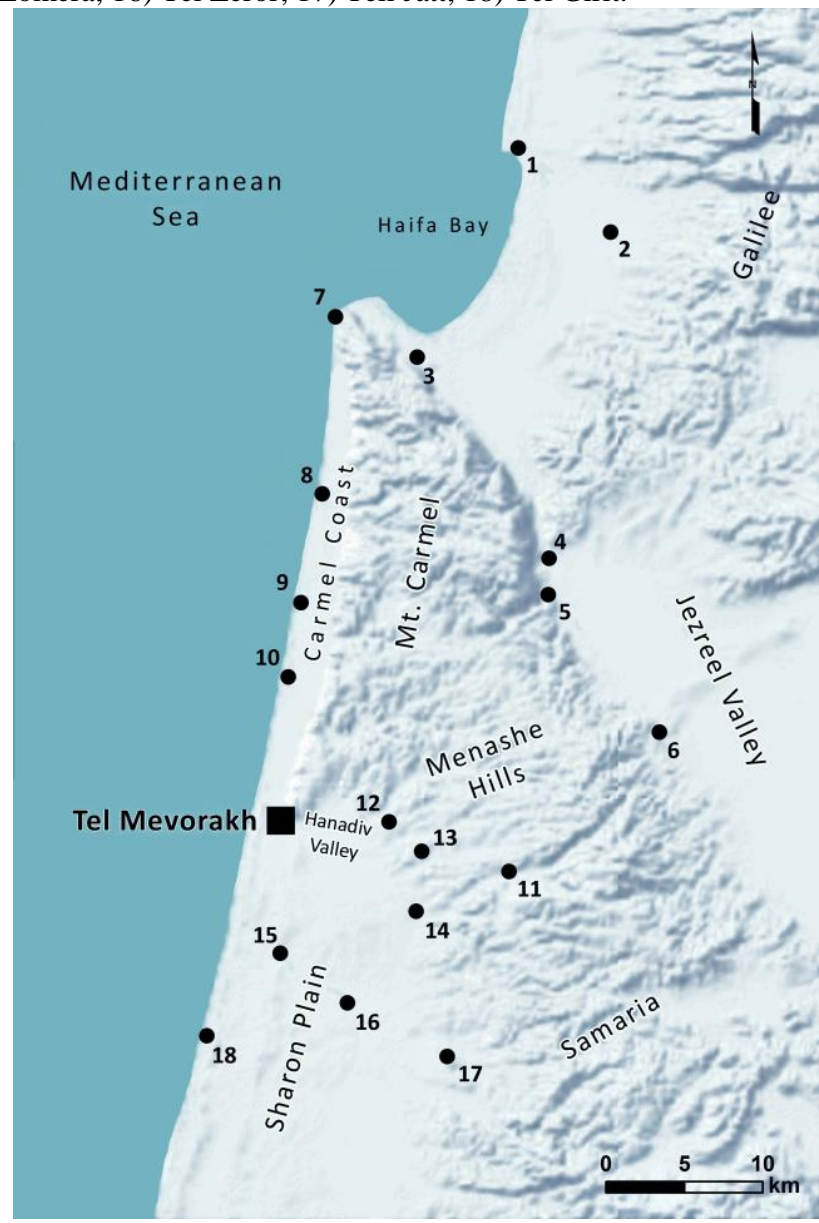

interpretation that the sanctuary was isolated (ibid:3, 170) should be dismissed. About the isolated structure at Amman airport, its identification as a temple is questionable. If it is a cult site, it is of a unique nature (Herr, 1983). Therefore it is a different situation than that of Tel Mevorakh, in which the temple itself is not unusual (in comparison to other temples). Its uniqueness is only in its location. It is worth mentioning the temple of Stratum R-2 at Beth-Shean (15th century BCE), which seems to stands alone at the top of the mound (Mullins \& Mazar, 2007:112-138). By that, the Beth-Shean temple seems to join the temple of Tel Mevorakh, and perhaps also Fosse Temple I, as isolated temples dated to LB-I. 
Stern suggested that the temple was constructed by the native (sedentary) Canaanite population of the region. He refers to Tel Mevorakh as a daughter site of Tel Dor "the capital of the district", ${ }^{4}$ which he believed to be a large and important port city already in the $15-14^{\text {th }}$ century BCE - the time of strata XI-X (Stern, 1984:1, 41, 65, 68-69). Regarding the special location of the temple, Stern suggested that the temple stood on a major crossroad on the main road leading to Dor. A route that he saw as a western section of the Via Maris. One of the main trading routes of the ancient near east. Consequently, he defined Tel Mevorakh as a "road sanctuary" that was used by travelers and traders who visited the temple "while passing by" (ibid: 35-36, 40-41, 44; Stern, 2000:51-53). Mazar suggested, on the basis of certain architectural features, that the Tel Mevorakh temple was used by foreign population, especially merchants of Aegean or Cypriot origin. It seems that for Mazar, the isolated location of the temple confirms that its worshippers were foreigners that were forced to practice their cult outside the Canaanite settlements (Mazar, 1980:62-68). ${ }^{5}$ Finkelstein ${ }^{6}$ suggested based on the isolated location of Tel Mevorakh that it was used as a cult center of pastoral nomad population (Finkelstein, 1986:310). ${ }^{7}$

In agreement with Stern, I think that the temple was related to the local Canaanite population who lived in the surrounding area. There are no unique finds or building styles that clearly point to a foreign population. I also tend to agree with Stern that we need to understand the temple in relation to the sedentary population in this area, although I do not entirely exclude the possibility that some pastoral nomads also lived in this area, and took part in the cult at the site. ${ }^{8}$

I suggest reexamining the nature of the Tel Mevorakh temple by drawing attention to the ancient natural landscape in which the temple once stood. In my opinion this can cast doubt on Stern's interpretation of the temple as a "road sanctuary", and point to another option: the temple as monument that marks a unique natural place in the landscape, a place which was seen by its worshipers as a liminal space between the divine world and the human world.

\section{ThE ANCIENT NATURAL AND HuMAN LANDSCAPE}

The Taninim River, where Tel Mevorakh is located on the south bank, is a natural border between two geographical regions on the Israeli coastal plain: the Sharon plain to the south, and the Carmel coast to the north. North of the river there is also the southern tip of the Carmel mountain range, "The Carmel Nose" (Hotem HaCarmel). The edge of that "nose" is about 600 meters east of Tel Mevorakh and rises to about $130 \mathrm{~m}$ above its surroundings. In ancient times the Carmel Mountain was covered with dense Mediterranean forest, as it is (primarily) still today.

The Sharon is a relatively wide strip of land ${ }^{9}$ between the Mediterranean Sea in the west and the mountains of Samaria and the Menashe Hills to the east, from the Yarkon River in the

\footnotetext{
${ }^{4}$ Stern, 1984:1.

5 "Tel Mevorakh... could have served as harbor for foreign merchants and traders" (Mazar, 1980:66). See Stern response: Stern, 1984:36.

${ }^{6}$ See also: Bunimovitz, 1994:199.

${ }^{7}$ Nadav Na'aman in response to Finkelstein's suggestion, notes the possibility that "out-of-town cultic sites" may be part of the urban cult, as known from Anatolia and Mesopotamia (Na'aman, 1994:234).

${ }^{8}$ Joint worship of nomads and sedentary population is well known in the history of the southern Levant also in later periods. For example, at the festival of Nebi-Musa in the Ottoman period and in early British Mandate times (Canaan, 1927:194).

${ }^{9}$ In the Northern Sharon, the width of the strip is between $9-12 \mathrm{~km}$.
} 
south to the Taninim River and Mount Carmel in the north. The Sharon can be generally divided into three longitudinal substrips: a. The eastern strip is a shallow and fertile alluvial valley beside the western foothills of the Samaria Mountains. b. The central strip which characterized by rolling hills of red soil (hamra). Those hills were not suitable for cultivation in ancient times and because of that they were left covered (partly until the modern era) by a forest of oak trees (Quercus ithaburensis). ${ }^{10}$ c. The western strip is represented by one to three sandstone (kurkar) ridges with narrow valleys between them. Until the modern era, this strip was characterized by swamps (mainly in the winter), which covered large areas of those valleys and between the sandstone ridges and the hamra hills (of strip b.) (Karmon, 1959; Faust, 2007, 65).

In the northern Sharon, the eastern strip of fertile alluvial soil (a.) expands and becomes a fertile valley called "Hanadiv Valley". This valley is surrounded by the low Menashe Hills in the east and north, Mount Carmel in the northwest, and two hamra hills in the west and south. ${ }^{11}$ The Taninim River flows from the Menashe Hills in the east, cross the Hanadiv Valley, and goes through an opening between the eastern hamra hill and the southern tip of the Carmel. Tel Mevorakh located around 800 meters west of that opening, on the southern bank of the river. The site itself, located at the northern edge of the Sharon, between the hamra hill of strip b., and a sandstone ridge of strip c. (Roller, 1982:49-50; Karmon, 1959:114). ${ }^{12}$

The Carmel Coast, north of Tel Mevorakh, is a narrow strip of land between the sea and the Carmel mountain range, from the Taninim River in the south up to the point the Carmel meets the sea in the north. In the area of Tel Mevorakh, the width of this strip is about $2.5 \mathrm{~km}$, and it is divided into two longitudinal sub strips: a sandstone ridge close to the sea in the west, and a plain strip of alluvial soil in the east. The sandstone ridge is essentially a continuation of the ridge from the Sharon coast that was divided by the Taninim River (Ben-Arieh et al., 1962a).

The LB settlement in the northern Sharon was located primarily in relation to the fertile alluvial soil in the east, beside and on top the Menashe Hills (See Fig.3; Karmon, 1959:122; Stern, 1984:42-44; Ne'eman, 1990; Gadot \& Tepper, 2009; Olami et al., 2005b). The main sites are: Tel Esur, Tel Eran, Khirbet Sitt Leila, Tel Zeror and Tell Jatt. Apart from these, few known sites sit directly on the coastline as Tel Girit (Karmon, 1959:125; Ne'eman, et al., 2000; Olami et al., 2005b). ${ }^{13}$ The majority of those northern Sharon sites were not extensively excavated.

The closest known LB settlement to Tel Mevorakh is Kh. Sitt Leila, a mound of about 3 to 4 hectares in size, that is located also on the south bank of the Taninim River, about $7 \mathrm{~km}$ east of Tel Mevorakh. Until today, only very limited excavations were done at this site, so its actual size and nature in the LB are unknown (Gadot \& Tepper, 2009: No.138; Kovo, 1993;

\footnotetext{
${ }^{10}$ Patches of that forest were preserved till the beginning of the $20^{\text {th }}$ century CE. They are seen clearly in the map of the SWP (Conder \& Kitchener, 1880). Those hills were cultivated only in the modern era with modern technology of transporting water.

${ }^{11}$ On the eastern hamra hill today sits the modern town of Binyamina and on the southern hill the towns of Pardes-Hanna and Karkur.

${ }^{12}$ On that sandstone ridge today sits the modern village of Jisr az-Zarqa.

${ }^{13} \mathrm{Tel}$ Zomera is a quite exceptional site, regarding its location. It sits between the hamra hills and sand dunes, in relation to the alluvial soils of the banks of the Hadera Stream (Olami et al., 2005b: Site No. 28).
} 
Kovo, 1991; Aharoni, 1959:112-116). ${ }^{14}$ The largest site in this area is Tell Jatt $(18.3 \mathrm{~km}$ southeast of Tel Mevorakh) which seems to be the location of Ginti-Kirmil or Gitti-Padalla. Two Canaanite city-states mentioned in the Amarna correspondence from the $14^{\text {th }}$ century BCE (Goren et al., 2004:248, 256-257). This large mound is now covered by the modern village of Jatt.

In the Carmel Coast, the LB settlements were located primarily on the sandstone ridge close to the sea shore and functioned as small port sites - Tel Nami, Tel Megadim, Tel Shiqmona and Tel Dor (Artzy, 2006; Stern, 1984:41-42; Olami et al., 2005a; Ronen \& Olami, 1978). Tel Dor, to which Stern attributes Tel Mevorakh (Stern, 1984:1), is located 9.3 $\mathrm{km}$ north of the temple and is under extensive excavation for the last forty years. Unfortunately, the exact nature of Dor at the LB is still unclear, but it seems now to be quite different than the large port city which Stern described in Tel Mevorakh's final report (ibid:1,41). Now it is known that the large Iron Age city of Dor was founded, in the west and south of the site, directly on the bedrock (areas B1, D2). Because of that, it seems that the LB site of Dor was significantly smaller, and was concentrated in the northwest close to the shore. ${ }^{15}$ The limited LB remains that were found at that site are dated to the $13^{\text {th }}$ century BCE, later than the temple of Tel Mevorakh (Gilboa \& Sharon, 2008: 149-151). Also in the historical record, Dor first appears in the $13^{\text {th }}$ century, in the time of king Ramesses II of the $19^{\text {th }}$ dynasty (Ahituv, 1984:88-89). This of course does not mean that Dor did not exist earlier in the LB, but it seems to have been a smaller and less important site, probably similar to Tel Nami, and the other small Carmel coastal sites that were mentioned.

Hence the Tel Mevorakh temple was located in isolation, at a meeting point of different geographical regions: the Sharon, the Carmel Coast, and not far from the "Carmel Nose", between the fertile alluvial valley of Hanadiv Valley in the east and a sandstone ridge and the sea in the west.

Important natural elements in the close vicinity of the Tel Mevorakh temple, which are in my opinion crucial for its understanding, are the water sources. Not far to the north of the site runs the Taninim River, which is one of the major rivers of the Israeli coastal plain (second only to the Yarkon River). The estimated flow in this river in the past per year was between 100 to 110 million cubic meters. The Taninim River's origin is in springs in the Manasseh hills and it became much more significant close to Tel Mevorakh due to contributions from more springs in the foot of Mount Carmel (Perlmuter, 2008:7-6, 8, 20; Negev, 1966: 20-21). So in the vicinity of the temple, the river was at the peak of its volume.

Near the site, the river also joins another major water source, a large marsh named Kabara. Until the beginning of the $20^{\text {th }}$ century CE, the Kabara Marsh was the second largest permanent marsh in Israel. It covered an area of about 600 hectares, from the area of Tel Mevorakh in the south almost to Dor in the north, from the slopes of the Carmel in the east to the sandstone ridge in the west. The marsh was a shallow wetland with thick vegetation and numerous water pools and springs (Conder \& Kitchener, 1882:2-4, 35; Stieglitz 2006:3-7; Ben-Arieh et al.1962b:58; Avitzur 1988:51-52). In the map of the Survey of Western Palestine (SWP) from about 1880 (Conder \& Kitchener, 1880; See Fig.4), as in an aerial photograph done in 1918 (See Fig.5), Tel Mevorakh is seen almost as an island or a small peninsula on the southern shore of that large marsh, surrounded from the north and west (and

\footnotetext{
${ }^{14}$ Y. Aharoni suggests identifying Kh. Sitt Leila with $\underline{d} f t^{\prime}$. A city mentioned in the annals of Thutmoses III's first campaign (Aharoni, 1959). N. Na'aman suggests it the site of Ginti Kirmil Known from the Amarna letters (Na'aman, 1986:466).

${ }^{15}$ LB stratum was reached only in area G (Gilboa \& Sharon, 2008: 149-150).
} 
perhaps also south) ${ }^{16}$ by the marsh. Those two intertwined water sources were joined also by a seasonal stream called Ada, which joins the Taninim River about 350 meters to the west of Tel Mevorakh.

Fig. 4: Part of the map of the Survey of Western Palestine (SWP) 1880: sheet VII (Conder \& Kitchener, 1880)

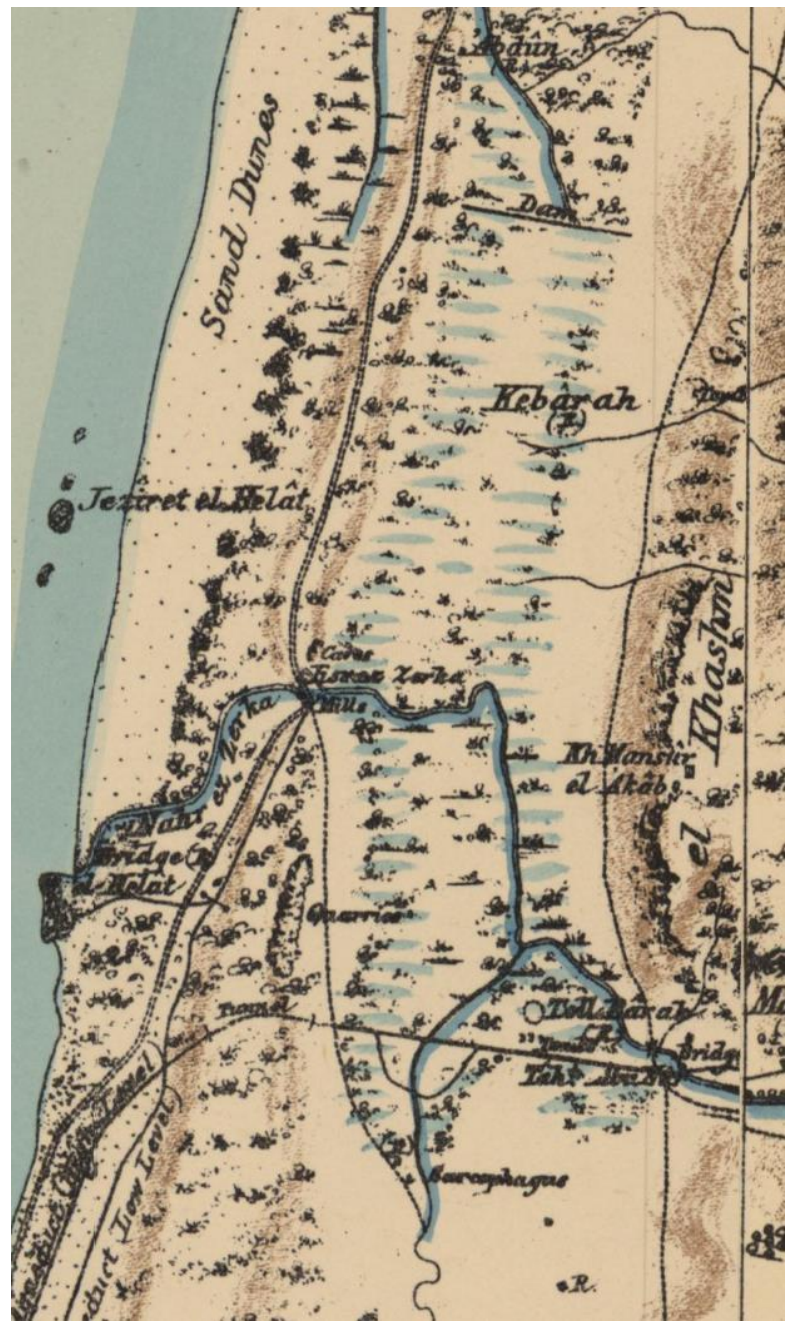

\footnotetext{
${ }^{16}$ See the SWP map (Conder \& Kitchener, 1880). South of the site the modern village of Beit-Hanania was built by PICA in 1950. In the newspapers of that time, it was said that the village was built on a land that was covered in the past by the marsh (Davar 30.6.1950: 8; Al-HaMishmar 30.6.1950: 8). For those articles, see the website of "Historical Jewish Press": http://web.nli.org.il/sites/JPress/Hebrew/ Pages/default.aspx
} 
Fig. 5: Aerial photograph of the area of Tel Mevorakh, done by the Australian Flying Corps at 1918. View from southwest.

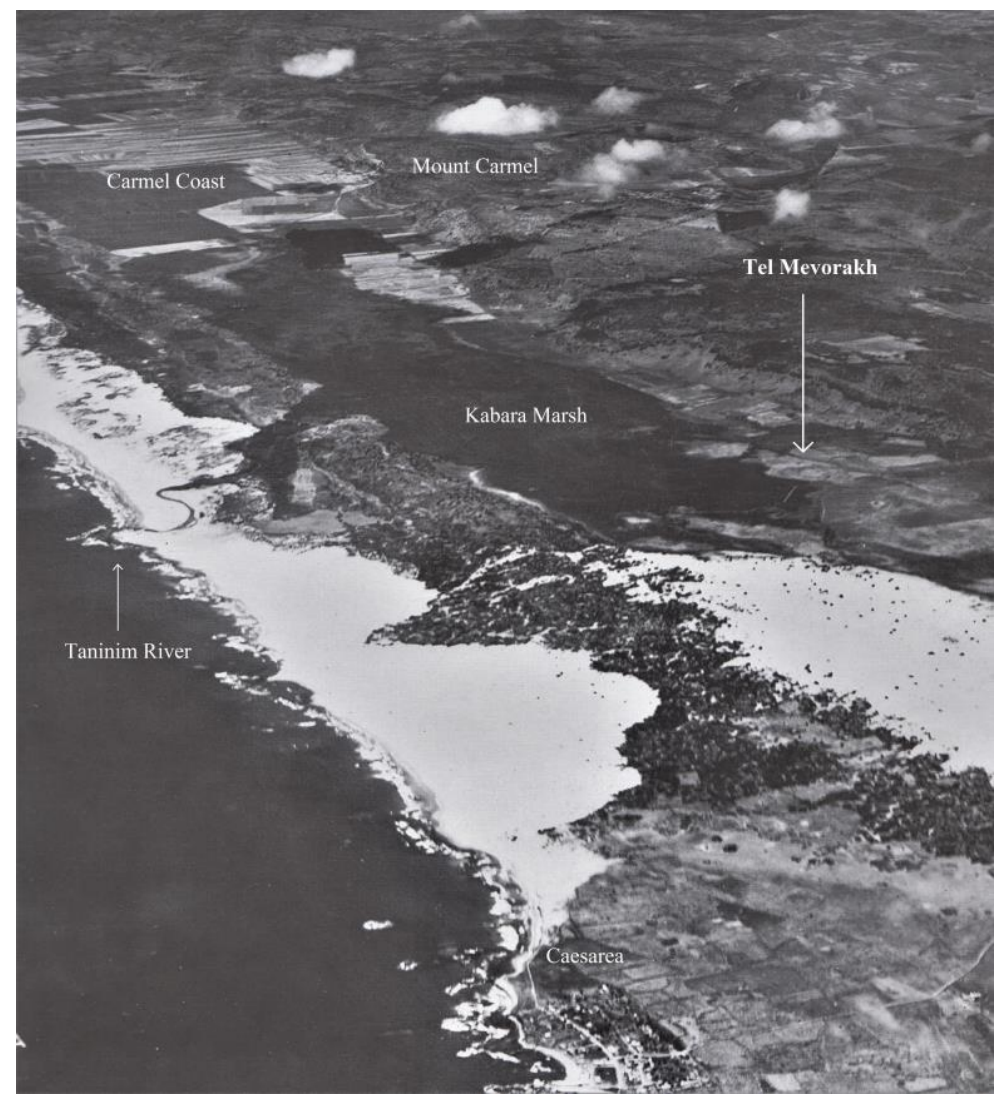

In 1925-1926 the marsh was deliberately drained and dried in an engineering project by the Palestine Jewish Colonization Association (PICA). In this project the courses of the Taninim River and the Ada Stream were slightly changed to planned channels (Avitzur, 1988). Because of that, today they run a bit further from Tel Mevorakh than what they did before (as seen in the SWP map: Conder \& Kitchener, 1880). Today the Taninim River is also significantly smaller than in the past because of intensive water pumping in its springs. Currently, the flow is only 25 million cubic meters per year (Perlmuter, 2008:8). After the marsh was drained, three modern settlements were built in its territory: Beit-Hanania, Jisr az-Zarqa, and Ma'agan Michael. ${ }^{17}$ So it is important to understand that the natural surroundings of the Tel Mevorakh temple were changed very dramatically in the modern era.

The existence of the marsh also in ancient times is supported by the faunal remains found in the excavation of nearby Tel Dor, in its early Iron Age layers. Among the wild animals that were observed, there were remains of hippopotami (Hippopotamus amphibius) and softshell turtles (Trionyx triunguis), animals that are known to live in marsh surroundings and banks of rivers. A few bones of wild oxen (Bos Primigenius) were also found (Raban-Gerstel et al., 2008:45, 48; Sapir-Hen et al., 2014:88-89). It seems that this large and extinct animal also

\footnotetext{
${ }^{17}$ Davar 26.8.1949
} 
lived in marshy areas. From the Bronze and Iron Age archaeozoological record, it is possible to see that the distribution of wild oxen in those periods was in the coastal plain (where they were found together with hippopotami) and in the north of the Jezreel Valley, two areas that were characterized by swamps (Tsahar et al., 2009:4, 8). ${ }^{18}$

Other wild animals that once roamed in the wetland near Tel Mevorakh were crocodiles, the animals that gave their name to the Taninim River - "Crocodile River". This name for the river ${ }^{19}$ is mentioned already in the $1^{\text {st }}$ century CE, by Pliny the Elder (Natural History V, 17). He and Strabo (Geography XVI,2,27) also noted the existence of a ruined city nearby which was called "the crocodile city" - Crocodeilonpolis. ${ }^{20}$ The crocodiles themselves are mentioned clearly in the crusader period. For example: in the "Itinerary of King Richard" (the Lionheart) we are told that the army of the king camped on the banks of the river which they called "the River of Crocodiles", because once crocodiles from that river devoured two (crusader?) soldiers (Itinerarium Peregrinorum et Gesta Regis Ricardi 4.14; Stubbs, 1864). ${ }^{21}$ The crocodiles are mentioned also later, in written accounts of European travelers in the $18^{\text {th }}$ and $19^{\text {th }}$ centuries CE. The last crocodile was hunted in the river in 1912 (Stieglitz, 2006:4-7; Roller, 1982:47; Tsafrir, Di Segni, Green 1994a:106; Conder \& Kitchener, 1882:3). ${ }^{22}$

On the power and importance of those water sources in ancient times we can learn from the Roman and Byzantine activity around Tel Mevorakh. Probably already in the time of King Herod (37-4 BCE) waters from the springs which feed the Taninim River and the marsh were brought to Caesarea in an aqueduct. ${ }^{23}$ This aqueduct passes about $130 \mathrm{~m}$ south of Tel Mevorakh, and it suffered over time from damages caused by the unstable ground of the marsh. In the $4^{\text {th }}$ century CE, the swamp itself was used as a water source for Caesarea. Two dams were built, which limits its area, in order to create a large reservoir. Sometime in the $4^{\text {th }}$ century CE, the aqueduct near Tel Mevorakh collapsed, probably because of the strong water flow at the point where the Ada Stream joins the Taninim River and the Roman reservoir. When the Romans rebuilt it, for precaution, they rebuilt it slightly to the south only in this point near the site (Olami \& Peleg, 1975; Peleg, 1990; Porath et al., 2007; Negev, 1966). In a way, the Kabara Swamp that was known in the last few hundred years is this Roman reservoir in decline back to the natural marsh that was in the southern Carmel coast also before the construction of the dams.

When we think about the ancient landscape that surrounded the Tel Mevorakh Temple, we must understand that it stood on a hill above an area full of water: a strong perennial river and a large marsh that almost surrounds the mound from the north, west and maybe even from the

\footnotetext{
${ }^{18}$ Wild oxen were identified with animals known as rum in Ugaritic sources (KTU 1.10 II:10, III:20), and re'em (ראם) in the Bible (Nu 23:22; Dt 33:17; Is 34:7). In Ugaritic mythology, they are mentioned as wild animals that live in marshes, and banks of lakes (see below).

19 "Crocodilon Flumen" (Pliny, Natural History V,17), see: Tsafrir et al., 1994a:106.

${ }^{20}$ The city of Crocodeilonpolis was identified with the site of Tel Taninim on the mouth of the river (Stieglitz, 2006).

21 Another source from that period says that: "in the river of Caesarea there are crocodiles, horrible serpents“" (Stieglitz, 2006:4).

${ }^{22}$ Two kilometers to the north of Tel Mevorakh a small part of the Kabara swamp was preserved as a nature reserve. This reserve is around springs and a pool, that its Arabic name is Birket Timsah, meaning "the Crocodile pool". This name also keeps the memory of the crocodiles that once lived in this area.

${ }^{23}$ In the time of Herod, an aqueduct brought water from springs that located at the foot of the Mount Carmel. Later $\left(2^{\text {nd }}\right.$ century $\mathrm{CE}$ ) this aqueduct was extended to the source of the river, at springs in the Menashe Hills.
} 
south. These were wild natural surroundings in which crocodiles, hippopotami, and wild oxen once lived together with other animals.

\section{TEL MEVORAKH A SANCTUARY "ON AN IMPORTANT CrosSROAdS"?}

The Taninim River and the marsh where in ancient times, as in the pre-modern time, significant natural barriers making the passage in this area very difficult. The explorers of the SWP who visited the area in October 1873 reported that the Taninim River (Nahr ez Zarka) is "one of the most important streams in Palestine", and all along the course of that river, "on either bank" are "extensive marshes, entirely impassable" (Conder \& Kitchener, 1882:2-3). It is important to point out that they explore the region in October, a month in which (usually) the water sources in Israel are quite at their lowest level, before most of the winter rains have fallen and after a long dry summer. Even in this condition, the river and its marsh surrounding was "entirely impassable".

However, the British do mention in their written account and in their map three routes in which the crossing from the Sharon to the Carmel Coast was possible: the first way is on top of a Roman dam (in Arabic: Jisr ez Zerka); and the second was on the shore at the mouth of the river, where the river is shallow and narrow. Those two crossings were related to a route that went beside the western side of the sandstone ridge, about $1.5 \mathrm{~km}$ west of Tel Mevorakh. ${ }^{24}$ This ancient route is well known from the Roman period, evidenced by a number of milestones (Tsafrir et al., 1994b; Zigelman, 1981). Together with the dam, the Romans also built a bridge on the mouth of the river, near Tel Taninim. After the Roman period, and also after the bridge collapsed, those were still the main routes in this area (Stieglitz, 2006:7). ${ }^{25}$ They probably were also the main routes before the Romans organized them in their fashion.

In the SWP map (Conder \& Kitchener, 1880) another road is seen at the foot of Mount Carmel, about $800 \mathrm{~m}$ east of Tel Mevorakh. This route crossed the river on a bridge close to the edge of the "Carmel Nose", where the river is narrower. This route was marked on the map as less important and was also not mentioned in the text. ${ }^{26}$ It is possible that the passage in this route wasn't passable all year round, and in the winter when the marsh and the river overflowed, this road was blocked (Ben-Arieh et al., 1962b:49-50).

In any case, it seems that the Tel Mevorakh Temple was not located directly beside any of those roads, and certainly not in "a key position on an important crossroads" (Stern, 1984: 44). Although all the evidences that were presented here are later than the time of the temple, there is no reason to suggest a different route network in this region. The natural features that determined those two routes (one on the seashore or beside the sandstone ridge, and a second in the foot of the Carmel) were not changed, the river and the marsh most probably were there already in the LB. Because the river and the marsh were major natural barriers, those two routes were not the main roads that went from the Sharon to the north, they were local roads.

\footnotetext{
${ }^{24}$ See the SWP map (Conder \& Kitchener, 1880), and the map of: Tsafrir; et al., 1994b.

${ }^{25}$ In the late $19^{\text {th }}$ century CE, the Ottomans built a new bridge at the mouth of the river. This was done especially for the royal visit of Kaiser Wilhelm II to Palestine, who specifically asked to go from Haifa to Caesarea through the coast. Before the Kaiser special request, there were no proper-built roads in this region (Stieglitz, 2006:7).

${ }^{26}$ In 1936 the British built a modern road to Haifa which follows this route at the foot of the Carmel. This new road marks a significant change in the roadmap of the Carmel coast. This change became possible only after draining the swamp in the $1920^{\text {th }}$ (Ben-Arieh et al., 1962a:13-14).
} 
Yohanan Aharoni, based mainly on Egyptian sources, suggested that in the LB the main routes from the Sharon to the coast north of the Carmel went through mountain passes in the Menashe hills and the mountain of Samaria to the Jezreel Valley. From there, the route went north to Akko (Aharoni, 1987:38-39, map.3; Aharoni \& Avi-Yonah, 1993: map.10). The reason that the main routes went this way, and not through the Carmel Coast is that it is shorter, but more importantly, on this route, there are fewer natural barriers. One who chooses the coastal route to Akko will encounter on his way north a number of rivers and streams (at the peak of their flow) and their adjacent marshes. Apart from the Taninim River and the Marsh of Kabara, which are the most relevant to our discussion, a bit to the north is The Dalia River (also a perennial river that joined the Kabara marsh). North of the Carmel there are two rivers, the Kishon and the Na'aman, ${ }^{27}$ which also had some marshes around them. Because of those natural barriers the majority of the military campaigns that went through the southern Levant, chose to go through the Jezreel Valley and not by the Carmel Coast on their way to (or from) the north. For example, Thutmose III, Amenhotep II, Seti I, Rameses II (Aharoni \& Avi-Yonah, 1993:31-32, 35, 38, 40-41), Napoleon (Gihon, 2003: 118-119) and Allenby (Gihon, 1974:109).

Because of the natural barriers of the river and the marsh, Tel Dor (which Stern connects with Tel Mevorakh), although only $9.2 \mathrm{~km}$ north of the temple, seems to be more connected by land routes to the LB sites in the Haifa Bay and the Jezreel Valley than to Tel Mevorakh and the Sharon in general. Those are nearly two different road networks, which were joined together more to the east, in the Menashe Hills and the Jezreel Valley, at the central sites of Yokneam and Megiddo. Because of that, the affiliation of Tel Mevorakh to Dor seems very difficult.

From all the above, we see that there are difficulties in Stern's interpretation of the temple as a "Road sanctuary" on a main trading route to Dor. I believe Tel Mevorakh should be seen in relation to the northern Sharon sites, and perhaps especially in relation to Kh. Sitt Leila, which is located about $7 \mathrm{~km}$ to the east. Although, it is important to point out that the temple was quite far also from those Sharon sites and it seems to have had no eye contact with any of them. It sits on a lonely hill, far from any possible route, surrounded (at list) from the north and west by a marsh in which a major river flow. Hence, the key to the understanding of the Tel Mevorakh Temple is by this unique isolated location in the natural wilderness.

\section{Cult in Natural LANDSCAPE}

Tel Mevorakh stood in a prominent place in a wild natural area which was filled with water and wildlife. Above this watery area also stands the Carmel mountain ridge, and the temple's estimated entrance (in the east) seem to have been looking towards Carmel's southern tip (the "nose"). ${ }^{28}$ In my opinion, this relates to the universal human tendency to choose places for worship of the supernatural in places with some unique natural features. Places that by their "mystery" and "wonder" caused people to feel closer to the world of gods and spirits, and therefore were regarded as sacred. These were places such as mountains, prominent hills, caves, unique trees and groves, and also water sources such as rivers, springs, and swamps

\footnotetext{
${ }^{27}$ About the marsh of the Na'aman River see: Pliny the Elder, Natural History V.17, XXXVI.65. Today Ein Afek nature resort.

${ }^{28}$ In a later period, a tomb-shrine (maqām) of a Muslim saint was built on the "Carmel Nose" (Ziv, 1986). This can attest to the inclination to sanctify this specific part of the mountain, because of its prominent place in the landscape.
} 
(Ökse, 2011: 219-220; Peatfield, 2009: 251-253; Pedley, 2005: 39; Canaan, 1927:3, $6-7,63)^{29}$

In the southern Levant already in the Chalcolithic period, there are examples of a cult in relation to water sources, at the Shrine of Ein-Gedi which was located on a prominent hill overlooking the Dead Sea and in close vicinity to a spring (Ussishkin, 1980; Ussishkin, 2014). ${ }^{30}$ In the MB, the cult site at Nahariya, which, based on its finds, seems to be dedicated to a goddess, is situated north of the (modern day) bank of the Ga'aton River and not far from the seashore and a spring. It also quite an isolated temple, found about $270 \mathrm{~m}^{31}$ north of the settlement at Tel Nahariya (Naeh, 2012: 2-26; Dothan, 1956; Ben-Dor, 1951). In the Iron Age, an important cult center was established on the edge of the city of Dan, close to major springs and a river that is one of the main tributaries of the Jordan River. Mt. Hermon is also visible from the Dan sanctuary (Biran, 1994:161-162). ${ }^{32}$

In the Hebrew Bible, there are many references of springs and wells that were seen as meeting places of men and the divine. ${ }^{33}$ The Jordan River, that has its source at Dan, was seen as a political and geographical border. On its banks, Joshua built a site of standing stones (Josh 4:3-9), and the eastern tribes of Israel built a large altar (Josh 22:10-29). The Jordan was also related to a number of miraculous stories about its crossing (Josh $4 ; 2 \mathrm{Kgs}$ $2: 8,14)$, and one story that tells about its healing powers (2Kgs 5:14-10). Later, in the New Testament, we are told about the Jorden as the place where Jesus was baptized (Matt 3:13-17; Mark 1:9-11; Luke 3:21-23), a ritual that is still practiced in the Jordan by many pilgrims today.

At the Persian and Classical Periods, on the Phoenician coast, isolated cult sites for local gods were built in relation to sacred rivers and springs (Grinberg, 1991:16-17, 68-69; Jidejian, 1968: 122-124, 127-128). In Paneas (Banias), a cult for the Greek god Pan was performed from the $3^{\text {rd }}$ century BCE till the mid $-5^{\text {th }}$ century CE, at a temple complex in relation to springs, a river, and caves at the foot of Mt. Hermon (Berlin, 1999:27-31). ${ }^{34}$

Pliny mentioned that the marshes of the Na'aman River (north of Mt. Carmel) were regarded sacred. The river itself was named Belus, a name that seems to be related to the Canaanite god Baal, and then it may be perceived as sacred too, as the Adonis River and the Asclepius River in the Phoenician coast (Natural History V.17, XXXVI.65). ${ }^{35}$

\footnotetext{
${ }^{29}$ See Ezekiel 6:1-5 for the location of rural cult sites in the kingdom of Judah: mountains, hills, valleys

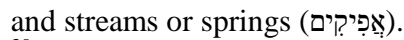

${ }^{30}$ Amihai Mazar suggests that together with the spring the shrine was built also in relation to a sacred tree, which stood in the middle of the shrine's courtyard (Mazar, 2000).

31 The distance between the shrine (ITM: 768238 / 208880) and the recent excavation at Tel Nahariya (ITM: 208860 / 767960) (Amitzur et al., 2016; Getzov \& Frankel, 2012: site No.1).

32 The cult in the "sacred precinct", as A. Biran (the excavator) saw it, also included active involvement of the spring's water. Biran points to a built spring pool and a terracotta tub that was found near it. Also in the Roman period, a pool for the water of the spring was built, what called "the fountain house" (Biran, 1994:174, 230-231).

${ }^{33}$ See for example: Gen. 16:7-14; 21:31-33; 26:23-26; Num. 20:7-12; Jud. 15:15-19; 1Kgs. 1:9; 1:33. Perhaps also Gen. 38:14. This verse mentions a place called Petah 'Einayim near the road to Timnah, in which Tamar dressed as a "sacred prostitute". The name can be understood as a place of springs ('ein). If so, it literally "the opening (place) of springs".

${ }^{34}$ The sanctuary at Paneas was first founded as an isolated cult site and later was incorporated into a Roman city (Berlin, 1999). The unique nature of Paneas also gave rise to a cult-site in the ottoman period. In this case, for a Muslim holy man that was said to be buried there, and a small shrine (maquam) was contracted on his tomb. Till the beginning of the $20^{\text {th }}$ century CE, sick people came to that shrine to be healed, and animals were sacrificed (Paton, 1919-1920: 56-58).

${ }^{35}$ Also Josephus tells of the river Belos as a place of wonder (Jewish War II.10:189).
} 
Marshes, as other water sources, were also regarded as sacred in the popular Muslim traditions in the Levant. Those were seen as the dwelling of the spirits of holy men and women as well as Jinns (Paton, 1919-1920:55-56; Canaan, 1927:37-38,63-69,111). For example, the El-Matba'ah swamp that was in the north of the Jezreel Valley was said to gain healing powers from Sheikh Abreik, a holy man whose tomb-shrine (maqām) was located on a nearby hill. Sick worshipers used to bathe in the swamp and then went up the hill to give offerings to the holy man at its shrine (Canaan, 1927:42, 64, 111).

Those examples show the longue durée of cult in springs, rivers, and marshes in the Levant. A popular cult that derives, first of all, from the general human tendency to the worship in natural places, and from the specific natural features of the region. ${ }^{36}$ Therefore we see how through the ages the inhabitants of the Levant, although of different faiths and cultures, chose to practice cult in relation to sacred water sources. Many more examples can be found in other regions as Hittite Anatolia (Ökse, 2011:219,225-227), the Greek and Roman world (Pedley, 2005:30-39,182-184; Guettel Cole, 1994:204-209, 2016); ${ }^{37}$ and even Iron Age North West Europe, in which human sacrifice were given to sacred bogs (Green, 1998:177-179). The Tel Mevorakh temple should be seen, as another example of this type of cult phenomenon.

\section{LIMINAL SPACE BETWEEN THE HUMAN AND MYTHICAL WORLD.}

A narrow window into the Canaanite beliefs regarding swamps and rivers can be provided from the mythological texts that were uncovered at the site of Ugarit on the Syrian coast. In those stories, we can get the feeling that swamps, rivers, and springs, had a special place in the world of the Canaanite gods.

In one story (KTU 1.10), that is usually attributed to the "Baal Cycle", we are told that the god Baal went hunting wild oxen in the swamp of Shamak $(\check{s} m k){ }^{38}$ The wild oxen which Baal hunts are named rumm, the Ugaritic equivalent of the Hebrew: re 'emim (רָאִמִים). These identified as Bos-primigenius, beasts that (as mention before) used to live also in the marshes of the Carmel Coast (Haniel, 1929; Bilik, 1973). ${ }^{39}$ The Goddess Anat followed Baal to the hunting ground, and the two seem to make love, perhaps in the form of wild oxen (The tablet is quite fragmentary). At some point, a cow, perhaps Anat herself (!), gave birth to a calf. After this, Baal goes back to Mount Șaphon (spn), his dwelling place. Anat than follows him, and declares the birth of a wild ox as a son to Baal (Wyatt, 2002: 155-160).

\footnotetext{
${ }^{36}$ Natural features which are very different in comparison to Egypt and Mesopotamia, the neighboring regions that their landscape is more arid and dominated by very large rivers. therefore the best comparisons to isolated cult sites in relation to water sources can be found in other areas in the Mediterranean region, as Anatolia, Greece, Italy and Crete.

${ }^{37}$ An interesting example is the cult of the Goddess Marica in Italy. Her shrine was located on an island surrounded by swamps, close to the sea and the mouth of a river. That goddess was perceived as the goddess of the river and the swamp (Salyer, 1947; Livi, 2006: 90-112).

${ }_{38} a h$ šmk - The Ugaritic word use here for swamp (or shore) is $a h$. The equivalent of the Hebrew word $a h u$ (אָז), which means an area of reeds and rushes. In the two Biblical appearances of that word, it relates to watery areas. In Gen. 41:2,18 the banks of the Nile, and in Job. 8:11 a swamp. smk is the name of a specific swamp, which most scholars seem to agree that it is the large marsh that was in the Hula valley in northern Israel (Brown et al., : 28 \{BDB\}; del Olmo Lete \& Sanmartín, 2004: 36, 825).

${ }^{39}$ Margalit suggests regarding this story that the rumm are water buffalos (Margalit, 1989: 78). But those animals seem to be brought to the Levant only in The Umayyad period (Amar \& Serri, 2005).
} 
Another Ugaritic myth (KTU 1.92) tells about the goddess Astarte, who also went to a swamp in order to hunt wild oxen. Later, with a bull she hunted, she feeds various gods in her house (Wyatt, 2002: 370-374). ${ }^{40}$

Those two stories give a vivid picture of the swamp as a place which the gods are active in, they hunt, $^{41}$ they meet other gods, and they make love. Also, the wild oxen, who roam the marshes, are seen as animals with some mythical aspect: Gods make love with them and/or gods are transformed into them, and those wild animals are also hunted by the gods in order to feed gods. ${ }^{42}$

In the Ugaritic texts, we also hear that El, the father of the gods, dwells in a mountain sanctuary that described as "the source of the rivers, amidst the springs of the two deeps" (ibid:99 / KTU 1.2 III 4), ${ }^{43}$ clearly some kind of a mythical spring. Besides that, one of the main gods of the Ugaritic pantheon was the god Yam ("Sea"), which in many appearances in the texts is also referred to as "ruler river" ( $t p t n h r)$, and "king river" $(m l k n h r) .{ }^{44}$

The above examples, from the Ugaritic texts, show the mythic affiliation of water sources in the Canaanite worldview. Those kinds of beliefs, in my opinion, drew worshipers to Tel Mevorakh. It was probably seen as a site that was, in the eyes of the local Canaanites, a monument which marks a border - a liminal space - between the human world, the settlements and the cultivated area east of the temple, and the divine world where gods dwell and are active in the wild sacred landscape of the river and marsh.

This mythical landscape could have included also Mount Carmel - a mountain that is known from the Bible to be related to the cult of the Canaanite god Baal, and the God of Israel (1 Kgs 18:20-40), ${ }^{45}$ and in the classical period was seen as the dwelling place of a god which was identified with Zeus, and/or was named Carmel (Tacitus, Histories, II:78; Roller 1982:47-48; Avi-Yonah 1952).

\section{The Possible Nature OF Worship that Was ASSOCIATED WITH THE TEMPLE.}

In ancient near eastern texts, there are references to cult practices performed in cult sites in natural and rural places. In Hittite Anatolia (LB) there were isolated cult sites in relation to sacred mountains, rocks, caves and water sources (Ökse, 2011: 219-220). ${ }^{46}$ Besides the textual evidence, those kinds of sites are also known from archaeology. They can include a shrine, a built pool, a relief on the side of a rock, or just a sacred stone. The word huwaši,

\footnotetext{
${ }^{40}$ For a different reading and interpretation, see: Margalit, 1989.

${ }^{41}$ In the mortuary temple of Ramses III at Medinet Habu, there is a monumental relief which shows the king hunting wild oxen on the banks of the Nile, or some marsh area filled with reeds. Although it could be a presentation of some real event, there is also a certain mythical aspect to it (Beierkuhnlein, 2015:110-114).

${ }^{42}$ In general, bulls are mentioned as nicknames for Baal and El (the father of the gods). Baal also appears sometimes in iconography as standing on a bull. Those traditions sprout also in the biblical tradition regarding the god of Israel (Ex. 32:4, Num. 23:22, 1 Kgs. 12:28).

${ }^{43}$ Appears also in: KTU 1.3 V 6-7; 1.4 IV 21-22; 1.6 I 33-34.

${ }^{44}$ For example: KTU 1.2 III 4; 1.3 V 6-7; 1.4 IV 21-22; 1.6 I 33-34.

${ }^{45}$ In the list of Thutmose III (I:48) appears a place called "the Holy Head" (Ra 'ši Qodšu) near (?) Akko, which Kallai, Aharoni, and Ahituv identified as Mt. Carmel. If this is the case, it could indicate the sanctity of the mountain already at the $15^{\text {th }}$ century BCE (Kallai, 1962:327; Ahituv, 1984:162-163; Aharoni, 1987:130).

${ }^{46}$ See for example the site of Eflatun Pinar (Ökse, 2011:225).
} 
often describe cultic sites of this nature (ibid: 228; Gurney, 1952:149; Singer, 2009:121; Zimmer Vorhaus, 2011:196). The ritual which was related to those huwaši sites seems to include (in many cases) a procession from the nearby settlements to the cult site as part of a festival. In some cases, the statue of a god, from the city's temple, was carried in the procession. In the huwaši site, various rituals took place, such as feasting and even performing plays which reenacted ancient battles and probably also myths (Gurney, 1952:155-156; Zimmer Vorhaus, 2011:196). About $1.5 \mathrm{~km}$ outside Hattusa is a famous rock sanctuary which is now called Yazilikaya. This temple was built in relation to springs and unique rocks. The cult in this shrine also included processions from the city's main temple, as part of festivals in honor of the chief gods of the pantheon. Itamar Singer suggests that those processions were reenacting a mythic procession of the gods (Singer, 2009:121-123, 172-173; Gurney, 1952:153).

Also in Babylon, there are references to processions toward temples outside the cities. In the spring festival of akitu, the statue of the god Marduk (the patron god of the city) was carried in a procession to a temple outside the city (bìt akiti). ${ }^{47}$ This was as part reenacting the myth of Enuma Elish. Marduk was taken outside to a place where he (again) "fought" Tiamat. A few days later, the statue was brought back as victorious in a second procession. In this ritual, the area outside the city, and especially the outer temple, marked the primordial chaos, while the return to the city's temple symbolizes the victory of order (Bidmead, 2002:94, 96, 118).

In LB Emar, in northern Syria, was a festival named Zukru, in which a procession was held to a sacred stone (sikkānu) somewhere outside the city. In the procession, the statue of the god Dagan (and on some occasions other gods too) was taken in a wagon. At the sacred stone, ceremonies were performed that included animal sacrifices (Fleming, 1995:142-144; Fleming, 2003; Cohen, 2007:331-333).

Unfortunately, in Ugarit, there is a lack of textual information about the nature of cult in the countryside. But there are some references to rituals that includes the carrying of deities in royal processions throughout the city. Pardee suggested the possibility that those can be deities that were brought from a rural sanctuary into the city (KTU 1.43; Pardee, 2002:69-72; Pardee, 2000: 70). The only "glimpse" we have to actual rituals in the rural areas seems to come from two texts (RS 13.006; RS 15.072; Pardee, 2002:119-122) that deal with sacrificial rituals. Unfortunately, they are very fragmentary, so the context in which the rituals takes place is not clear.

In the Greek and Roman world, the cult in many isolated sanctuaries is known thanks to historical written accounts as Pausanias's "Description of Greece" $\left(2^{\text {nd }}\right.$ century CE). In it, there are descriptions of numerous isolated cult sites in Greece and their related cult - a cult that was centered in festivals ${ }^{48}$ which included (in many cases) processions of a very similar nature to the rituals mentioned above (Alcock, 1993:172-173, 202-206; Osborne, 1987:166-170). ${ }^{49}$

\footnotetext{
${ }^{47}$ The name of the shrine - bìt akìti - seem to indicate that this shrine was operating only at the time of the akitu festival, or at list that this was its main cultic function.

${ }^{48}$ In some cases, those isolated shrines where even open only in the time of the festival. For example the temple of Eurynome (which located near hot springs), that was open one day a year while in the rest of the time it considered a sin to open it (Alcock, 1993:204).

${ }^{49}$ For example: At the city of Helos a wooden statue of Persephone was taken from the city to a sanctuary about $35 \mathrm{~km}$ from Helos. (Pausanias, Description of Greece: 3.20:7; Alcock, 1993:203-204).
} 
Nadav Na'aman (1994:234), suggested that the rituals known from texts in Anatolia and Mesopotamia in relation to "out-of-town cultic sites" (which were mention above), can explain the possible nature of worship in isolated cult sites also in the southern Levant. Based on Na'aman's suggestion, and the examples which were presented, I suggest that the main ritual that took place in relation to the Tel Mevorakh temple was in a festival. Festival in which a procession could have been held between Tel Mevorakh and a temple of a main settlement in the region. The Procession could include carrying a statue of a deity, and some ceremony at the large courtyard in front of the temple. That suggested festival was probably related to some mythical story that involved the deity of the Tel Mevorakh temple and the natural surroundings of the site. Except for the time of the festival, throughout the year the temple could have been visited by individual worshipers, who sought the help of the temple's deity.

\section{Tel Mevorakh as a Political "Border Sanctuary"}

Tel Mevorakh is located south of a significant natural barrier, which most probably in ancient times marked a political border between two different Canaanite political entities. This border was suggested by Na'aman, who attributes the northern Sharon (and in it Tel Mevorakh) to the territory of Gitti-Padalla (Jatt). In his view, the marshes of the southern Carmel Coast marked the border between the territory of this polity and that of Dor, which he saw as a major port city in the LB (Na'aman 1986:466). ${ }^{50}$

In the MB IIA, the "fortress" that was identified at Tel Mevorakh (strata XV-XIV) was clearly related to the major city of Tel Burga (25 ha.), a site located at the center of Hanadiv Valley, on the southern bank of the Taninim River. This fortress could have defended the border of a political entity in which Tel Burga was at the center or at least a major site in it. From the very limited excavations that were done at Tel Burga, it seems that it was occupied only in the MB IIA (Golani, 2011, Kochavi et al., 1981:43-53). If so, the center of power in the northern Sharon in the MB IIB and LB moved to some other site. In my opinion, Kh. Sitt Leila, which is located few kilometers to the east, may be a good candidate. In the very limited excavation that was conducted at this site, the entire sequence of the MB and LB was observed (Kovo, 1991; Kovo, 1993; Gadot \& Tepper, 2009: No.138).

I suggest that Tel Mevorakh continues to the LB as a marker of the border of this northern "Sharonite" polity, ${ }^{51}$ in this period as a "border sanctuary". A category of sanctuaries which is known well from the city-states of the Greek world (Alcock, 1993:172-173, 202; De Polignac, 1995: 32-88). This concept was suggested before by Aren Maeir, regarding the MB rural temples of Tel Kittan, Kfar-Ruppin and Tell el-Hayyat (Maeir, 2003:63-64); and by Y. Aharoni, regarding cult sites of the kingdoms of Israel in Judea (Aharoni, 1969). If the Tel Mevorakh temple is indeed a "border sanctuary" (in the Greek model), the temple had also a political function, which of course was intertwined with the religious function as a marker of a religious liminal space. In that case, the festivals with their processions from the settlements to the isolated border temple, as suggested above, were a ritual in which the

\footnotetext{
${ }^{50}$ Bunimovitz (1995: 328, Fig.11), and Finkelstein (1996: 234, Map.1) suggested that a border in the area of the Carmel Coast was north of Dor, marked by the Oren stream. By that, they include Dor as part of a Sharonite polity: Gitti-Padalla (Jatt) in Finkelstein's view and Ginti-Cirmil (Kh. Sitt Lyla) in Bunimovitz's.

${ }^{51}$ Perhaps a marker of the north border of the city-state which centered at the large mound of Jatt (Ginti Kirmil or Gitti-Padala), which Kh. Sitt Leila was its northern daughter site.
} 
community and its rulers defined their territory (Alcock, 1993:172-173, 202; Osborne, 1987: 168-170).

\section{Conclusions}

The reason that drew the local Canaanites to establish a cult site at Tel Mevorakh was its unique location in the ancient landscape, an isolated site far from any settlement and roads on the banks of a river and a marsh. It was surrounded by major water sources that were probably regarded as sacred by the locals together with the wild animals that lived in them.

The temple was part of the settlement system of the northern Sharon, which was mainly concentrated on the slopes of the Menashe hills to the east of the temple. For those sites, Tel Mevorakh was probably seen as a marker of a liminal space, a place that sits at the edge of their human world, of cultivated fields and settlements, and overlooks the divine mythical world where the gods were active, in the wild natural surroundings of Tel Mevorakh.

The significant natural barriers of the river and the marsh also seem to form a political border between a polity in the northern Sharon and the sites of the Carmel coast in the LB. If so, the temple should be seen also as a political "border sanctuary".

About the nature of the cult, I suggest the possibility that the main cultic activity in the temple was practice in a time of a festival that included a procession from the settlement in the east (or from a specific city temple), and ended with a ceremony at the temple of Tel Mevorakh.

\section{REFERENCES}

Aharoni, Y. (1959). Zephath of Thutmose. Israel Exploration Journal. 9(2), pp. 110-122.

Aharoni, Y. (1969). Israelite Temples in the Period of the Monarchy. Proceedings of the World Congress of Jewish Studies. 1, pp. 69-74.

Aharoni, Y. (1987). Eretz Israel in Biblical Times - A Geographical History. Jerusalem: Yad Izhak Ben-Zvi Publications. (Hebrew).

Aharoni, Y \& Avi-Yonah, M. (1993). The Macmillan Bible Atlas - Completely Revised Third Edition. Jerusalem. New York. Oxford. Singapore. Sydney: Carta, Macmillan Publishing Company.

Ahituv, S. (1984). Canaaite Toponyms in Ancient Egyptian Documents. Jerusalem, Leiden: The Magnes Press - The Hebrew University, Brill.

Amar, Z. \& Serri, Y. (2005). When did the water buffalo make its appearance in Eretz Israel?. Cathedra. 117, pp. 63-70. (Hebrew).

Amitzur, Y., Be'eri. R. \& Getzov, N. (2016). "Tel Nahariyya", Hadashot Arkhologiyot. 128. Retrieved April, 2016 from: http://www.hadashot-esi.org.il/Report_Detail_Eng. aspx?id=25093\&mag_id=124.

Alcock, S.E. (1993). Graecia Capta - The Landscapes of Roman Greece. Cambridge: Cambridge University Press.

Artzy, M. (2006). The Carmel Coast during the Second Part of the Late Bronze Age: A Center for Eastern Mediterranean Transshipping. Bulletin of the American Schools of Oriental Research. 343, pp. 45-64.

Avi-Yonah, M. (1952). Mount Carmel and the God of Baalbek. Israel Exploration Journal. 2(2), pp. 118-124. 
Avitzur, S. (1988). The Kabara Swamps and Dov Kovlanov - Exterminator. in: Biger, G \& Shiler, E (eds.). Sites and Places in Eretz-Israel (pp. 51-60). Jerusalem: Ariel. (Hebrew).

Beierkuhnlein, C. (2015). Bos primigenius in Ancient Egyptian art. Frontiers of Biogeography. 7(3), pp. 107-118.

Berlin, A.M. (1999). The Archaeology of Ritual: The Sanctuary of Pan at Banias/Caesarea Philippi. Bulletin of the American Schools of Oriental Research. 315, pp. 27-45.

Ben-Arieh, Y., Nashiv, Y. \& Reichman, S. (1962a). The Southern Carmel Coastal Plain. Yediot Bahaqirat Eretz-Israel Weatiqoteha. pp. 3-14. (Hebrew).

Ben-Arieh, Y., Nashiv, Y. \& Reichman, S. (1962b). Land Utilization in the Southern Carmel Coastal Plain. Yediot Bahaqirat Eretz-Israel Weatiqoteha. pp. 48-70. (Hebrew).

Ben-Dor, I. (1951). A Canaanite Temple at Nahariya. Eretz-Israel: Archaeological, Historical and Geographical Studies. 1, pp. 17-28. (Hebrew).

Bidmead, J. (2002). The Akitu Festival - Religious Continuity and Royal Legitimation in Mesopotamia. New Jersey: Gorgias press.

Bilik, E. (1973). The re'em. Beit Mikra: Journal for the Study of the Bible and Its World. 3, pp. 382-386. (Hebrew).

Biran, A. (1994). Biblical Dan. Jerusalem: Israel Exploration Society, Hebrew Union College.

Brown, F., Driver, S.R. \& Briggs, C.A. The Brown-Driver-Briggs Hebrew and English lexicon: With an appendix containing the Biblical Aramaic. Peabody: Hendrickson.

Bunimovitz, S. (1989). The Land of Israel in the Late Bronze Age: A Case Study of Socio-Cultural Change in a Complex Society. Tel Aviv: $\mathrm{PhD}$ dissertation, Tel Aviv University.

Bunimovitz, S. (1994). Socio-Political Transformations in the Central Hill Country in the Late Bronze-Iron I Transition. in: Finkelstein, I \& Na'aman, N (eds.). From Nomadism to Monarchy - Archaeological and Historical Aspects of Early Israel (pp. 179-202). Jerusalem: Yad Izahak Ben-Zvi, Israel Exploration Society.

Canaan, T. (1927). Mohammedan Saints and Sanctuaries in Palestine. London: Luzac.

Cohen, Y. (2007). Public Religious Sentiment and Personal Piety in the Ancient Near Eastern City of Emar during the Late Bronze Age. Religion Compass. 1(3), pp. 329-340.

Conder, C.R \& Kitchener, H.H. (1880). Map of Palestine in 26 sheets. one inch to a mile 1/63,360, Sheet VII. London Palestine exploration fund. Retrieved August, 2017 from: http://amudanan.co.il/.

Conder, C.R. \& Kitchener, H.H. (1882). The survey of western Palestine: memoirs of the topography, orography, hydrography, and archaeology - Vol. II: Sheets VII-XVI-Samaria. London: Palestine exploration fund.

del Olmo Lete, G \& Sanmartín. J. (2004). A dictionary of the Ugaritic language in the alphabetic tradition. Leiden, Boston: Brill.

de Polignac, F. (1995). Cults, territory, and the origins of the Greek city-state. Chicago, London: University of Chicago press.

Dothan, M. (1956). The Excavations at Nahariyah: Preliminary Report (Seasons 1954/55). Israel Exploration Journal. 6(1), pp. 14-25.

Eisenberg, E. (1977). The Temples at Tell Kittan. The Biblical Archaeologist. 40(2), pp. 77-81. 
Falconer, S.E. (1995). Rural Responses to Early Urbanism: Bronze Age Household and Village Economy at Tell el-Hayyat, Jordan. Journal of Field Archaeology. 22(4). pp. 399-419.

Faust, A. (2007). The Sharon and the Yarkon Basin in the Tenth Century BCE: Ecology, Settlement Patterns and Political Involvement. Israel Exploration Journal. 57(1). pp. 65-82. Finkelstein, I. (1986). The Archaeology of the Period of Settlement and Judges. Tel Aviv: Hakibbutz Hameuchad, Israel Exploration Society.

Finkelstein, I. Middle Bronze Age 'Fortifications': A Reflection of Social Organization and Political Formations. Tel Aviv, 19:2 (1992). pp. 201-220.

Finkelstein, I. (1996). The Territorial-Political System of Canaan in the Late Bronze Age. Ugarit-Forschungen. 28, pp. 221-255.

Fleming, D.E. (1995). More Help from Syria: Introducing Emar to Biblical Study. The Biblical Archaeologist. 58(3), pp. 139-147.

Fleming, D. (2003). The Zukru Festival (1.123). in: Hallo, W.W (ed.). The Context of Scripture - Archival Documents from the Biblical World - Vol.1 (pp. 431-436). Leiden, Boston: Brill

Franken, H.J. (1992). Excavation at Tell Deir 'Alla - The Late Bronze Age Sanctuary. Louvain: Peeters Press.

Gadot, Y \& Tepper, Y. (2009). Regavim - 49. The Archeological Survey of Israel. Retrieved April, 2009 from: http://www.antiquities.org.il/survey/new/default_en.aspx.

Getzov, N \& Frankel, R. (2012). 'Amqa - 5. the Archaeological Survey of Israel. Retrieved April, 2009 from: http://www.antiquities.org.il/survey/new/default_en.aspx.

Gihon, M. (1974). Carta's Atlas of Palestine from Bethther to Tel Hai: Military History. Jerusalem: Carta.

Gihon, M. (2003). Napoleon in the Holy Land. Efi Meltzer. (Hebrew).

Gilboa, A. \& Sharon, I. (2008). Between the Carmel and the Sea - Tel Dor's Iron Age Reconsidered. Near Eastern Archaeology. 71(3), pp. 146-171.

Golani, A. (2011). A Built Tomb from Middle Bronze Age II A and Other Finds at Tel Burga in the Sharon Plain. 'Atiqot. 68. pp.69-98.

Goren, Y., Finkelstein, I. \& Na'aman. N (eds.). (2004). Inscribed in Clay - Provenance Study of the Amarna Letters and other Ancient Near Eastern Texts. Tel Aviv: Emery and Claire Yass Publications in Archaeology.

Gurney, O.R. (1952). The Hittites. Melbourne, London: Baltimore Pelican Books.

Guettel Cole, S. (1994). Demeter in the Ancient Greek City and its Countryside. in: Alcock, S.E \& Osborne, R (eds.). Placing the Gods -Sanctuaries and Sacred Space in Ancient Greece (pp. 199-216). Oxford: Clarendon press.

Green, M. (1998). Humans as Ritual Victims in the Later Prehistory of Western Europe. Oxford Journal of Archaeology. 17(2), pp 169-190.

Grinberg, J.D, (1991), Hellenistic Phoenicia, Oxford: Clarendon Press.

Haniel, E. (1929). The re'em (wild ox - Bos-primigenius). Leshonenu: A Journal for the Study of the Hebrew Language and Cognate Subjects, pp.228-233. (Hebrew).

Herr, L.G. (1983). The Amman Airport Structure and the Geopolitics of Ancient Transjordan. The Biblical Archaeologist. 46(4), pp. 223-229.

Jidejian, N. (1968). Byblos Through the Ages. Beirut: Dar el-Machreq. 
Karmon, Y. (1959). Geographical Conditions in the Sharon Plain and their Impact on its Settlement. Bulletin of the Israel Exploration Society. pp. 111-133. (Hebrew).

Kallai, Z. (1962). Carmel, Mount Carmel. in: Encyclopaedia Biblica (Vol IV, pp. 324-329). Jerusalem: Bialik Institute. (Hebrew).

Kedar, B.Z. (1991). Looking Twice at the Land of Israel: Aerial photographs from 1917-18 and 1987-91. Jerusalem: Yad Ben-Zvi Press. Ministry of Defence.

Knauf, E.A. (1978). The Uniqueness of the LB Temple at Tell Mevorak. The Biblical Archaeologist, 41(4), p. 135.

Kochavi, M., Beck, P. \& Gophna, R. (1981). Aphek-Antipatris, Tel Poleg, Tel Zeror and Tel Burga: Four Fortified Sites of the Middle Bronze Age IIA in the Sharon Plain. Eretz-Israel: Archaeological, Historical and Geographical Studies. 15, pp. 28-62.

Kovo, G. (1991). Tel Zefi. Hadashot Arkheologiyot. 96. p. 43. (Hebrew).

Kovo, G. (1993).Tel Zefi - 1991 / - 1991. Hadashot Arkheologiyot. 100. pp. 31-32. (Hebrew). KTU = Dietrich, M., O. Loretz, O. \& Sanmartín, J. (1995). The Cuneiform Alphabetic Texts from Ugarit, Ras Ibn Hani and Other Places. Münster: Ugarit-Verlag.

Livi, V. (2006). Religious Locals in the Territory of Minturnae Aspect of Romanization. in: Harvey, P.B \& Schultz, C.E (eds.), Religion in Republican Italy (pp. 90-116). Cambridge: Cambridge University Press.

Maeir, A.M. (2003). Does Size Count? Urban and Cultic Perspectives on the Rural Landscape during the Middle Bronze II Period. in: Maeir, A.M., Dar, S. \& Safrai, Z (eds.), The Rural Landscape of Ancient Israel (pp. 61-69). Oxford: BAR International Series. Margalit, B. (1989). KTU 1.92 (Obv.): A Ugaritic Theophagy. Aula Orientalis. 7, pp. 67-80. Mazar, A. (1980). Excavation At Tell Qasila - Part One: The Philistine Sanctuary Architecture and Cult Objects. Jerusalem: Qedem 12. The Hebrew University of Jerusalem.

Mazar, A. (2000). Sacred Tree in the Chalcolithic Shrine at En Gedi: A Suggestion. Bulletin of the Anglo-Israel Archaeological Society. 18, pp. 31-36.

Mullins, R.A \& Mazar, A. (2007). The Stratigraphy and Architecture of the Middle and Late Bronze Ages: Strata R-5 - T-1A. in: Mazar, A \& Mullins, R.A. Excavations at Tel Beth-Shean 1989-1996 - Vol. III: The Middle and Late Bronze Age Strata in Area R. Jerusalem: Israel Exploration Society, The Institute of Archaeology, The Hebrew University of Jerusalem, pp.39-241.

Münnich, M. (2005). The Cult of Bronze Serpents in Ancient Canaan and Israel. Iggud: Selected Essays in Jewish Studies. 1, pp. 39*-56*.

Na'aman, N. (1986). The Canaanite city-states in the Late Bronze Age and the inheritances of the Israelite tribes. Tarbiz. 55, pp. 463-488. (Hebrew).

Na'aman, N. (1994). The 'Conquest of Canaan' in the Book of Joshua and in History. in: Finkelstein, I. \& Na'aman, N (eds.), From Nomadism to Monarchy - Archaeological and Historical Aspects of Early Israel (pp. 218-281). Jerusalem: Yad Izahak Ben-Zvi, Israel Exploration Society.

Naeh, L. (2012). Miniature Vessels and Seven-Cupped Bowels in the Middle Bronze Age Temple of Nahariya - Their Role and Meaning in Light of Cultic Miniature and Complex Vessels of the Middle Bronze Age. Jerusalem: The Institute of Archaeology. The Hebrew University of Jerusalem. (Hebrew).

Ne'eman. Y. (1990). Ma'anit - 54. The Archeological Survey of Israel. Retrieved November, 2015 from: http://www.antiquities.org.il/survey/new/default_en.aspx. 
Ne'eman, Y., Sender, S. \& Oren, E. (2000). Mikhmoret - 52, Hadera - 53. The Archeological Survey of Israel. Retrieved April, 2007 from: http://www.antiquities. org.il/survey/new/default_en.aspx.

Negev, A. (1966). New Inscriptions from the High-Level Aqueduct of Caesarea. Yediot Bahaqirat Eretz-Israel Weatiqoteha. 30(1-2), pp. 136-141. (Hebrew).

Ökse, A.T. (2011). Open Air Sanctuaries of the Hittites. in: Genz, H. \& Mielke, D.P (ed.). Insights into Hittite History and Archaeology (pp. 219-240). Leuven, Paris: Colloquia Antiqua. Peeters.

Olami, Y. \& Peleg, Y. (1975). The Aqueducts of Caesarea. Qadmoniot: A Journal for the Antiquities of Eretz-Israel and Bible Lands. 30/31(2/3), pp. 83-86. (Hebrew).

Olami, Y., Sender, S. \& Oren. E. (2005a). Dor - 30. The Archeological Survey of Israel. Retrieved June, 2005 from: http://www.antiquities.org.il/survey/new/default_en.aspx.

Olami, Y., Sender, S. \& Oren. E. (2005b). Binyamina - 48. The Archeological Survey of Israel. Retrieved June, 2005 from: http://www.antiquities.org.il/survey/new/default_en.aspx. Osborne, R. (1987). Classical Landscape with Figures - The Ancient Greek City and its Countryside. London: Sheridan House.

Pardee, D. (2000). Ugaritic Studies at the End of the 20th Century. Bulletin of the American Schools of Oriental Research. 320, pp. 49-86.

Pardee, D. (2002). Ritual and Cult at Ugarit. Atlanta: Society of Biblical Literature.

Paton, L.B. (1919-1920). Survivals of Primitive Religion in Modern Palestine. The Annual of the American School of Oriental Research in Jerusalem. 1, pp. 51-65.

Pedley, J.G. (2005). Sanctuaries and the Sacred in the Ancient Greek World. Cambridge, New York, Melbourne, Madrid, Cape Town, Singapore, Sao Paulo: Cambridge University Press.

Peleg, Y. (1990). The Storage Lake of the Low-Level Aqueduct to Caesarea. Cathedra: For the History of Eretz Israel and Its Yishuv. 56, pp. 19-32. (Hebrew).

Peatfield, A. (2009). The Topography of Minoan Peak Sanctuaries Revisited. Hesperia Supplements - Essays on Ritual and Cult in Crete in Honor of Geraldine C. Gesell. 42, pp. 251-259.

Perlmuter, M. (2008). Springs and Streams in Israel 2008 - Report of The Society for the Protection of Nature on the State of the Water in the Springs and the Streams. The Society for the Protection of Nature in Israel, Retrieved April, 2008 from: www.teva.org.il.

Porath, Y., Gendelman, P. \& Arnon, Y. (2007). An Ancient Flour Mill on the Northern Dam of the 'Tanninim Reservoir'. 'Atiqot. 56, pp. 151-166. (Hebrew).

Raban-Gerstel, N., Zohar, I., Bar-Oz, G., Sharon, I. \& Gilboa, A. (2008). Early Iron Age Dor (Israel): A Faunal Perspective. Bulletin of the American Schools of Oriental Research. 349, pp. 25-59.

Roller, D. (1982). The Northern Plain of Sharon in the Hellenistic Period. Bulletin of the American Schools of Oriental Research. 247, pp. 43-52.

Ronen, A. \& Olami, Y. (1978). 'Atlit - 26. The Archeological Survey of Israel. Retrieved July, 2016 from: http://www.antiquities.org.il/survey/new/default_en.aspx.

Rothenberg, B. (1993). Timna : in: Stern, E. The New Encyclopedia of Archaeological Excavations in the Holy Land. 4. Jerusalem: Israel Exploration Society, pp. 1475-1486.

Salyer, W.C. (1947). Swamp Goddess. The Classical Journal. 42(7), pp. 407-413. 
Sapir-Hen, L., Bar-Oz, G., Sharon, I., Gilboa, A. \& Dayan, T. (2014). Food, Economy, and Culture at Tel Dor, Israel: A Diachronic Study of Faunal Remains from 15 Centuries of Occupation. Bulletin of the American Schools of Oriental Research. 371. pp. 83-101.

Singer-Avitz, L. (2004). The Pottery of the Late Bronze I Phase. in: Ussishkin, D, The Renewed Archaeological Excavations at Lachish - Vol. III (pp. 1012-1032). Tel Aviv: Emery and Claire Yass Publications in Archaeology.

Singer, I. (2009). The Hittites and their Civilization. Jerusalem: The Biblical Encyclopaedia Library, Bialik Institute. (Hebrew).

Stern, E. (1976). Tel Mevorakh 1975. Israel Exploration Journal. 26(1), pp. 49-50.

Stern, E. (1977). A Late Bronze Temple at Tell Mevorakh. Biblical Archaeologist. 40(2), pp. 89-91.

Stern, E. (1984). Excavation at Tel Mevorakh (1973-1976) - Part Two: The Bronze Age. Jerusalem: Qedem 18. The Hebrew University of Jerusalem.

Stern, E. (2000). Dor: Ruler of the Seas - Nineteen Years of Excavations at the Israelite-Phoenician Harbor on the Carmel Coast. Jerusalem: Israel Exploration Society.

Stieglitz, R.R. (2006). Tel Tanninim: Excavations at Krokodeilon Polis - 1996-1999. Boston: American Schools of Oriental Research.

Stubbs, W (ed.). (1864). Itinerarium Peregrinorum et Gesta Regis Ricardi. London: Longman. Green. Longman. Roberts. and Green.

Tsafrir, Y., Di Segni, L. \& Green, J. (1994a). Tabula Imperii Romani - Iudaea-PalestinaEretz Israel in the Hellenistic, Roman and Byzantine Periods - Maps and Gazetteer. Jerusalem: The Israel academy of sciences and humanities.

Tsafrir, Y., Di Segni, L., Roll, I. \& Tsuk, T. Tabula Imperii Romani - Iudaea Palastina Eretz Israel in the Hellenistic, Roman and Byzantine Periods, North, 1:250,000, Survey of Israel. in: Tsafrir, Y., Di Segni, L. \& Green, J. (1994b). Tabula Imperii Romani Iudaea-Palestina - Eretz Israel in the Hellenistic, Roman and Byzantine Periods - Maps and Gazetteer. Jerusalem: The Israel academy of sciences and humanities.

Tsahar, E., Izhaki, I., Lev-Yadun, S. \& Bar-Oz, G. (2009). Distribution and Extinction of Ungulates during the Holocene of the Southern Levant. Plos One. 4(4), pp. 1-13.

Ussishkin, D. (1980). The Ghassulian Shrine at En-Gedi. Tel Aviv. 7, pp. 1-44.

Ussishkin, D. (2004). A Synopsis of the Stratigraphical, Chronological and Historical Issues. in: Ussishkin, D. The Renewed Archaeological Excavations at Lachish - Vol.I (pp. 50-119). Tel Aviv: Emery and Claire Yass Publications in Archaeology.

Ussishkin, D. (2014). The Chalcolithic Temple in En-Gedi - Fifty Years after its Discovery. Near Eastern Archaeology. 77(1), pp. 15-26.

Wyatt, N. (2002). Religious Texts from Ugarit. London, New York: Sheffield Academic Press.

Zigelman, A. (1981). Tel Taninim, Milestones. Hadashot Arkheologiyot. 77. p. 18.

Zimmer-Vorhaus, C. (2011). Hittite Temples: Palaces of the Gods. in: Genz, H. \& Mielke, D.P (ed.). Insights into Hittite History and Archaeology (pp. 195-218). Leuven, Paris: Colloquia Antiqua. Peeters.

Ziv, Y. (1986). Does the 'Nose' of Mount Carmel Marks Rabbi 'Aqiva's Grave?. Cathedra: For the History of Eretz Israel and Its Yishuv. 39, pp. 44-50. (Hebrew). 